\title{
Peningkatan Pemahaman Konsep Peluang Kejadian Majemuk Melalui Model Pembelajaran Discovery Learning Berbantuan Alat Peraga Dadu
}

\author{
Yusnimi Warti ${ }^{1^{*}}$ \\ ${ }^{1}$ SMA Negeri 1 Ampek Angkek Kabupaten Agam \\ *e-mail: yusnimiw@yahoo.com \\ (Diterima: 20 April 2020, direvisi: 10 Mei 2020, disetujui: 30 Mei 2020)
}

\begin{abstract}
Abstrak
Penelitian ini bertujuan untuk mendeskripsikan pemahaman konsep peluang kejadian majemuk melalui model pembelajaran Discovery Learning berbantuan alat peraga dadu pada kelas XII di SMA N 1 Ampek Angkek, Kabupaten Agam, Sumatera Barat. Penelitian ini merupakan penelitian tindakan kelas kolaboratif dimana peneliti adalah guru dan teman yang berkolaborasi dalam melakukan penelitian. Subyek penelitian ini adalah peserta didik kelas XII MIPA 5 SMAN 1 Ampek Angkek, Kabupaten Agam, Sumatera Barat, TP 2019/2020 pada semester genap. Teknik pengumpulan data menggunakan observasi, tes, catatan lapangan dan dokumentasi. Teknik analisis data menggunakan reduksi data, penyajian data dan verifikasi atau penarikan kesimpulan sedangkan keabsahan data menggunakan trianggulasi teknik. Penelitian ini menggunakankan 2 siklus dimana setiap siklus terdiri dari dua kali pertemuan. Hasil penelitian ini menunjukkan bahwa ada peningkatan pemahaman konsep peluang kejadian majemuk dengan menggunakan model pembelajaran Discovery Learning berbantuan alat peraga dadu.
\end{abstract}

Kata Kunci: pemahaman konsep peluang kejadian majemuk, model pembelajaran, Discovery Learning, alat peraga dadu.

\begin{abstract}
This study aims to describe the understanding of the concept of multiple event opportunities through the Discovery Learning model assisted by the dice props in class XII at SMA N 1 Ampek Angkek, Agam Regency, West Sumatra. This research is a collaborative classroom action research where researchers are teachers and friends who collaborate in conducting research. The subjects of this study were students of class XII MIPA 5 of SMAN 1 Ampek Angkek, Agam Regency, West Sumatra, TP 2019/2020 in the even semester. Data collection techniques using observation, tests, field notes, and documentation. Data analysis techniques use data reduction, data presentation, and verification or conclusion drawing, while the validity of the data uses triangulation techniques. This study uses two cycles, where each cycle consists of two meetings. The results of this study indicate an increase in understanding the concept of multiple event opportunities by using the Discovery Learning model assisted by dice props.
\end{abstract}

Keywords: understanding the concept of multiple occurrence opportunities, Discovery Learning learning models, dice props 


\section{PENDAHULUAN}

Pada pembelajaran matematika diharapkan peserta didik benar-benar kreatif. Sehingga akan berdampak pada ingatan peserta didik yang akan lebih lama bertahan tentang apa yang akan dipelajari. Suatu konsep akan mudah dipahami dan diingat oleh peserta didik jika konsep tersebut disajikan melalui prosedur dan langkah-langkah yang tepat, jelas dan menarik keberhasilan itu dapat dilihat dari tingkat pemahaman, penguasaan materi serta prestasi belajar peserta didik. Semakin tinggi pemahaman dan penguasaan materi serta prestasi belajar maka semakin tinggi pula tingkat keberhasilan pembelajaran.

Pemahaman konsep matematika sangatlah penting bagi peserta didik dalam mempelajari matematika, karena pemahaman konsep matematika merupakan landasan dasar dalam mempelajari matematika [1]. Jika peserta didik telah memahami konsep-konsep dasar matematika, maka akan memudahkan peserta didik untuk memahami konsep-konsep selanjutnya [2].

Pemahaman konsep matematika dapat menentukan kemampuan peserta didik dalam menyelesaikan permasalahan matematika. Menurut peraturan Dirjen Dikdasmen Nomor $506 / \mathrm{C} / \mathrm{Keo} / \mathrm{PP} / 2004$ tanggal 11 November 2001 yang menyatakan bahwa indikator peserta didik dalam memahami konsep matematika adalah mampu untuk: 1) menyatakan ulang sebuah konsep, 2) mengklasifikasikan objek tertentu sesuai dengan konsepnya, 3) memberikan contoh dan bukan contoh dari suatu konsep, 4) menyajikan konsep dalam berbagai bentuk representasi matematis, 5) mengembangkan syarat perlu atau syarat perlu atau syarat cukup dari suatu konsep dan 6) menggunakan dan memanfaatkan serta memilih prosedure atau operasi tertentu, 7) mengaplikasikan konsep atau algoritma dalam pemecahan masalah.

Pemahaman konsep peserta didik di SMA N 1 Ampek Angkek, Kabupaten Agam, Sumatera Barat khususnya dalam materi peluang kejadian majemuk kejadian majemuk tahun pembelajaran 2018/2019 masih memprihatinkan. Hal ini dapat dilihat persentase indikator pemahaman konsep matematika peserta didik khususnya materi peluang kejadian majemuk antara lain 1) menyatakan ulang sebuah konsep peluang kejadian majemuk mencapai $70.58 \%$, 2) mengklasifikasi objek menurut sifat-sifat tertentu mencapai $69.65 \%$, 3) memberikan contoh dan bukan contoh mencapai 69.05\%, 4) menyajikan konsep peluang kejadian majemuk dalam berbagai bentuk representasi mencapai $67.70 \%, 5$ ) mengembangkan syarat perlu atau syarat cukup dari suatu konsep peluang kejadian majemuk mencapai $65.00 \%$,6) menggunakan dan memanfaatkan serta memilih prosedure atau operasi tertentu dalam peluang kejadian majemuk mencapai $65.56 \%$ dan 7) mengaplikasikan konsep peluang kejadian majemuk dalam pemecahan masalah mencapai $69.00 \%$.

Rendahnya pemahaman konsep peserta didik pada materi peluang kejadian majemuk kejadian majemuk dapat terjadi dikarenakan pembelajaran masih terpusat pada guru dan guru masih menggunakan model pembelajaran konvensional sehingga membuat peserta didik kurang aktif dan bosan selama pembelajaran berlangsung serta penggunaan alat peraga yang belum diterapkan membuat peserta didik kurang tertarik dengan materi. 
Salah satu model pembelajaran yang cocok untuk pemahaman konsep pada materi peluang kejadian majemuk kejadian majemuk yaitu model pembelajaran Discovery Learning [3]. Model pembelajaran Discovery Learning merupakan model pembelajaran kognitif yang menuntut guru lebih kreatif menciptakan situasi yang dapat membuat peserta didik belajar aktif menemukan pengetahuan sendiri. Dalam model pembelajaran Discovery Learning guru dan peserta didik sama-sama aktif membimbing penemuan pada eksperimen yang dilakukan peserta didik.

Penggunaan media pembelajaran sebagai alat bantu guru dalam penerapan model pembelajaran Discovery Learning juga dapat meningkatkan pemahaman konsep matematika peserta didik. Media pembelajaran atau alat peraga adalah segala sesuatu yang dapat digunakan oleh guru untuk menyalurkan pesan dan dapat merangsang pikiran, perasaan, perhatian dan kemampuan peserta didik dalam memahami suatu konsep. Penggunaan alat peraga dapat membantu peserta didik maupun guru dalam memahami konsep matematika yang akan diajarkan [4].

Hasil penelitian [5] menyimpulkan bahwa penggunaan media pembelajaran sebagai alat bantu guru dalam penerapan model pembelajaran Discovery Learning juga dapat meningkatkan pemahaman konsep matematika peserta didik sehingga akan berpengaruh pada peningkatan hasil belajar peserta didik. Model pembelajaran ini sangat baik digunakan untuk penemuan konsep dan membuat peserta didik lebih aktif selama pembelajaran berlangsung. Penelitian yang dilakukan merupakan penelitian tindakan kelas. Adapun tahapan penelitian antara lain perencanaan, pelaksanaan, observasi atau evaluasi dan refleksi.

Menurut Penelitian yang dilakukan oleh [6], penelitian yang dilakukan merupakan penelitian tidakan kelas yang menggunakan model pembelajaran Discovery Learning. Teknik pengumpulan data yang dikumpulkan melalui observasi, dan refleksi. Pada saat pembelajaran berlangsung dengan penggunaan model pembelajaran Discovery Learning peserta didik lebih aktif dan pembelajaran tidak terpusat pada guru, akan tetapi waktu yang diperlukan untuk penerapan model pembelajaran ini sangatlah banyak.

Penelitian yang akan dilakukan yaitu untuk meningkatkan pemahaman konsep matematika peserta didik khususnya materi peluang kejadian majemuk kejadian majemuk pada peserta didik kelas XII MIPA 5 SMAN 1 Ampek Angkek, Kabupaten Agam, Sumatera Barat, TP 2019/2020 pada semester genap melalui model pembelajaran Discovery Learning berbantuan alat peraga dadu.

\section{METODA}

Penelitian ini menggunakan penelitian tindakan kelas dengan jenis penelitian tindakan kelas kolaboratif dimana peneliti dan guru berkolaborasi dalam melakukan penelitian. Desain penelitian yang sesuai dengan Model Kurt Lewin. Pada Model Kurt Lewin menggambarkan tindakan sebagai suatu proses siklikal spiral yang meliputi: perencanaan, plaksanaan dan pengamatan [7].

Subjek penelitian adalah seluruh peserta didik di kelas XII MIPA 5 SMA Ampek Angkek Kabupaten Agam Sumatera Barat, yang terdiri dari 35 orang yang terdiri dari 18 orang laki-laki dan 17 orang perempuan. Data penelitian ini diperoleh melalui 
teknik pengumpulan data yaitu tes pemahaman konsep peluang kejadian majemuk, observasi, catatan lapangan dan dokumentasi. Hasil tes pemahaman konsep pada materi peluang kejadian majemuk berbantuan alat peraga dadu yang disesuaikan dengan indikator pemahaman konsep matematika yang digunakan untuk mengetahui pemahaman konsep pada materi peluang kejadian majemuk berbantuan alat peraga dadu peserta didik. Lembar observasi dan catatan lapangan yang digunakan untuk mencatat segala aktivitas tindak belajar peserta didik dan tindak mengajar penelit sebagai guru dalam menggunakan model pembelajaran Discovery Learning berbantuan alat peraga dadu. Dokumentasi yang digunakan untuk mendokumentasikan penggunaan model pembelajaran Discovery Learning berbantuan alat peraga dadu dan tes pemahaman konsep peluang kejadian majemuk serta hal-hal yang berhubungan dengan penelitian.

Teknik analisis data pada penelitian menggunakan reduksi data, penyajian data dan verivikasi atau penarikan kesimpulan. Keabsahan data pada penelitian ini menggunakan triangulasi teknik yaitu peneliti menggunakan teknik yang berbedabeda untuk mendapatkan data dari sumber yang sama. Peneliti menggunakan obsevasi, catatan lapangan dan dokumentasi.

\section{HASIL DAN PEMBAHASAN}

Hasil penelitian ini diperoleh dari hasil tes pemahaman konsep matematika dan hasil observasi dan catatan lapangan dari tindak mengajar peneliti sebagai guru matematika dan tindak belajar peserta didik kelas XII MIPA 5 SMA N 1 Ampek Angkek Kabupaten Agam Sumatera Barat. Penelitian ini dibagi menjadi 2 Siklus yaitu Siklus I dan Siklus II.

\section{Deskripsi Hasil Siklus 1}

Hasil dari diskusi perencanaan tindakan siklus I yaitu Rencana Pelaksanaan Pembelajaran (RPP) yang sudah disepakati oleh teman kolaborasi dan peneliti sebagai guru matematika. Pada pelaksanaan tindakan siklus I ini, peneliti sebagai guru yang memberikan tindakan sedangkan teman kolaborasi membantu proses pembelajaran matematika dalam melakukan observasi atau pengamatan proses pembelajaran yang berlangsung di kelas. Selama proses pembelajaran berlangsung teman kolaborasi mencatat kejadian-kejadian yang penting selama proses pembelajaran matematika berlangsung yang terdapat di lembar observasi, lembar catatan lapangan dan dokumentasi. Setelah pelaksanaan pembelajaran selesai, teman kolaborasi dan peneliti berdiskusi tentang tindak mengajar peneliti dan tindak belajar peserta didik setelah penggunaan model pembelajaran Discovery Learning berbantuan alat peraga dadu dan tes pemahaman konsep peluang kejadian majemuk.

Pertemuan pertama siklus I pembelajaran matematika dengan menggunakan model pembelajaran Discovery Learning berbantuan alat peraga dadu. Kegiatan pembelajaran diawali dengan salam pembuka dan menayakan keadaan peserta didik kemudian peneliti memberikan apersepsi dan menjelaskan tujuan pembelajaran dan model pembelajaan yang akan digunakan selama proses pembelajaran berlangsung. Adapun langkah-langkah tindak mengajar peneliti dengan menggunakan model pembelajaran Discovery Learning berbantuan alat peraga dadu. Tahap 1 pemberian rangsangan atau Stimulation, Pada tahap ini peneliti masih membantu peserta didik untuk mendapatkan 
informasi. Tahap 2 identifikasi masalah atau Problem Statement, peneliti mengelompokkan peserta didik yang terdiri dari 5 orang peserta didik dan memberikan permasalahan kepada peserta didik yang terdapat pada lembar kegiatan peserta didik. Tahap 3 pengumpulan data (Data Collection) setiap kelompok diberikan media pembelajaran yang berupa dua buah dadu oleh peneliti sebagai alat bantu peserta didik dalam menyeleseikan permasalahan pada lembar kegiatan peserta didik.

Tahap 4 Pengolahan Data (Data Collection) dan Tahap 5 Pembuktian (Verivikation) guru meminta peserta didik untuk menghimpun data dan mendiskusikan dengan kelompoknya. Selama diskusi berlangsung peneliti masih membantu peserta didik dalam menuliskan hasil diskusinya di lembar kegiatan peserta didik. Tahap 6 menarik kesimpulan (Generalisation) peneliti memanggil salah satu peserta didik untuk mempresentasikan hasil diskusi kelompoknya. Pada tahap ini peneliti dan peserta didik memberikan kesimpulan terhadap pembelajaran yang sudah dilakukan. Menutup pembelajaran dengan bacaan hamdallah. Selanjutnya pada pertemuan kedua siklus I diadakan tes pemahaman konsep pada peserta didik.

Hasil pengamatan tin dak mengajar pada siklus I masih belum optimal, selama proses pembelajaran berlangsung masih terpusat pada peneliti sehingga kelas belum bisa dikondisikan dengan baik. Waktu yang digunakan untuk melaksanakan model pembelajaran Discovery Learning berbantuan alat peraga dadu masih perlu tambahan jam. Pada saat pembagian alat peraga dadu terdapat beberapa kelompok yang malah memainkan dadu untuk bermain kegiatan lainn yang tidak berhubungan dengan materi pembelajaran. Pada saat diskusi kelompok dilakukan terdapat beberapa kelompok yang belum melakukan kegiatan menurut langkah-langkahnya, akan tetapi ada salah satu kelompok yang sudah melakukan kegiatan sesuai dengan langkah-langkah yang terdapat pada lembar kegiatan peserta didik. pada penarikan kesimpulan banyak peserta didik yang masih bingung dalam penarikan kesimpulan dan belum paham dengan langkah-langkah pembelajaran. Peneliti masih membimbing peserta didik untuk menyimpulkan keseluruhan kegiatan yang telah dilakukan. Selanjutnnya pertemuan kedua diadakan tes pemahaman konsep yang sesuai dengan indikator pemahaman konsep peserta didik. Banyak peserta didik yang ramai sendiri dan meminta jawaban dari teman lain.

Refleksi pada tindak mengajar peneliti sebagai guru matematika belum optimal dikarenakan peneliti belum sempurna dalam melakukan langkah-langkah model pembelajaran Discovery Learning berbantuan alat peraga dadu sehingga membuat kekurangan waktu pembelajaran. Timbulnya faktor-faktor tersebut membuat proses pembelajaran matematika pada siklus I belum sesuai harapan peneliti sehingga peneliti dan teman kolaborasi mendiskusikan alternatif solusinya antara lain: sebelum pembelajaran dimulai peneliti harus memahami kembali langkah-langkah model pembelajaran Discovery Learning berbantuan alat peraga dadu sehingga pembelajaran dapat berlangsung tepat waktu, dalam pelaksanaannya sebaiknya peneliti harus memberikan arahan yang tepat dan jelas kepada peserta didik, sebelum pembelajaran dimulai sebaiknya peneliti dapat mengkondisikan peserta didik terlebih dahulu. 
Selama proses diskusi belangsung peneliti sebaiknya tidak terfokus pada satu kelompok saja. Pada tindak belajar peserta didik ini belum optimal dikarenakan masih banyak peserta didik yang ramai, bermain sendiri, bingung dengan langkah-langkah penggunaan model pembelajaran Discovery Learning dan banyak peserta didik yang meniru jawaban teman lain. Alternatif tindakan yang dapat diterapkan untuk mengatasi masalah tersebut antara lain peserta didik sebaiknya banyak berlatih mengerjakan soal dan berlatih memahami suatu konsep matematika pada materi peluang kejadian majemuk dari cara bagaimana didapatkannya bukan langsung rumusnya. Adapun hasil dari rataratapersentase tes pemahaman konsep dari setiap indikator pemahaman konsep antara lain yaitu: 1) menyatakan ulang sebuah konsep peluang kejadian majemuk mencapai 72,45\%, 2) mengklasifikasikan konsep peluang kejadian majemuk menurut sifatnya mencapai 70,54\%, 3) memberikan contoh konsep peluang kejadian majemuk mencapai 70,47\%,4) menyajikan konsep peluang kejadian majemuk mencapai 69,81\%, 5) mengembangkan syarat perlu/syarat cukup dari suatu konsep peluang kejadian majemuk mencapai $71,26 \%$, 6) menggunakan konsep peluang kejadian majemuk mencapai $72.13 \%$, dan 7) mengaplikasikan konsep peluang kejadian majemuk dalam pemecahan masalah mencapai 69,98\%.

\section{Deskripsi Hasil Siklus II}

Perencanaan tindakan pada siklus II dibagi menjadi 2 pertemuan. Pertemuan pertama untuk pelaksanaan tindakan siklus I adalah pelaksanaan penerapan model pembelajaran Discovery Learning dengan berbantuan alat peraga matematika yang sesuai dengan Rencana Pelaksanaan Pembelajaran (RPP) yang telah disepakati bersama. Pada pelaksanaan tindakan siklus II ini, peneliti bertindak sebagai pemberi tindakan sedangkan teman kolaborasi membantu proses pembelajaran matematika dan melakukan observasi atau pengamatan proses pembelajaran matematika yang berlangsung di kelas. Selama proses pembelajaran berlangsung teman kolaborasi mencatat kejadian-kejadian yang penting selama proses pembelajaran matematika yang terdapat di lembar observasi, lembar catatan lapangan.

Pada pertemuan pertama pada siklus II pembelajaran matematika dimulai dengan mengucapkan salam dan berdoa selanjutnya menanyakan kabar peserta didik serta mengecek kehadiran peserta didik. Sebelum memulai pembelajaran, peneliti melakukan apersepsi yaitu mengingatkan kembali materi pada pertemuan sebelumnya, menyampaikan materi yang akan dipelajari, menyampaikan tujuan pembelajaran serta model pembelajaran yang akan digunakan selama proses pembelajaran dan menyampaikan manfaat pembelajaran materi peluang kejadian majemuk dalam kehidupan sehari-hari. Kegiatan pembelajaran berlangsung dengan menerapkan model pembelajaran Discovery Learning berbantuan alat peraga matematika. Pada kegiatan inti guru sudah menerapkan model pembelajaran Discovery Learning berbantuan alat peraga matematika sesuai dengan langkahlangkahnya. Guru sudah dapat mengkondisikan peserta didik saat mengelompokkan peserta didik, saat memberikan lembar kegiatan peserta didik, saat pelaksanaan kegiatan peserta didik dan saat penarikan kesimpulan sehingga pembelajaran matematika terlaksana dengan kondusif. Pada pertemuan I 
proses pembelajaran berlangsung lancar dan baik dibandingkan dengan siklus I, peserta didik sudah mulai dapat menggunakan model pembelajaran Discovery Lerarning dan berbantuan alat peraga dadu, sehingga peserta didik dapat mengikuti pembelajaran matematika dengan lebih fokus, lebih aktif dan sudah tidak merasa kebingungan lagi.

Hal ini dapat dilihat pada kegiatan inti dimana peserta didik sudah dapat mengikuti langkah-langkah pembelajaran Discovery Learning sesuai dengan lembar kegiatan peserta didik. Pada saat diskusi kelompok, peserta didik sudah berperan aktif didalam kelompoknya masing-masing sehingga peserta didik sudah tidak ramai lagi. Selama proses pembelajaran berlangsung, peserta didik aktif untuk menemukan rumus dengan menggunakan alat peraga 2 buah dadu yang sudah diberikan. Peserta didik sudah menggunakan dadu untuk membantu menyelesaikan permasalahan sesuai dengan langkah-langkah kegiatan peserta didik. Dalam hal ini, peran peserta didiklebih aktif sehingga pembelajaran sudah tidak terpusat pada peneliti sebagai guru. Penggunaan alat peraga dadu oleh peserta didik sudah sesuai dengan model pembelajaran Discover Learning. Pada siklus II pertemuan kedua, diadakan tes kemampuan pemahaman konsep peserta didik untuk mengetahui adakah peningkatan pemahaman konsep dengan menggunakan model pembelajaran Discovery Learning berbantuan alat peraga dadu, dapat dilihat dari tes kemampuan pemahaman konsep materi peluang kejadian majemuk yang setiap butir soal akan sesuai dengan indikator-indikatornya. Pada siklus II ini peserta didik sudah bisa mengerjakan sendiri tanpa harus mencontek jawaban teman lain. Tes pemahaman konsep yang diadakan pada siklus II ini sudah mengalami peningkatan sesuai dengan yang diharapkan.

Refleksi Tindakan Siklus II peneliti telah melaksanakan pembelajaran matematika sesuai dengan rencana pelaksanaan pembelajaran (RPP) dan meerapkan model pembelajaran Discovery Learning berbantuan alat peraga dadu pada materi peluang kejadian majemuk sesuai dengan yang diharapkan, dalam pelaksanaannya sudah mengalami perubahan sehingga pembelajaran berjalan kondusif. Dalam pelaksanaan tindakan siklus II ini, kegiatan pembelajaran mengalami perbaikan yang bagus. Terdapat peningkatan pemahaman konsep materi peluang kejadian majemuk peserta didik kelas XII MIPA 5 SMAN 1Ampek Angkek, Kabupaten Agam, Sumatera Barat. Pelaksanaan tindakan pada siklus II ini lebih meningkat dari padasiklus I.

Hal ini dapat dilihat dari hasil rata-rata persentase tes pemahaman konsep dari setiap indikator pemahaman konsep antara lain : yaitu 1) menyatakan ulang sebuah konsep peluang kejadian majemuk mencapai 83,25\%,2) mengklasifikasikan objek menurut sifat-sifatnya mencapai $81.20 \%$, 3) memberikan contoh konsep peluang kejadian majemuk mencapai $80,30 \%$, 4) menyajikan konsep peluang kejadian majemuk mencapai $80.21 \%$, 5) mengembangkan syarat perlu/syarat cukup dari suatu konsep peluang kejadian majemuk mencapai $81,25 \%$, 6) menggunakan konsep peluang kejadian majemuk mencapai $82,40 \%$, dan 7) mengaplikasikan konsep peluang kejadian majemuk dalam pemecahan masalah mencapai $80,18 \%$.

Berdasarkan hasil refleksi dari siklus II ini dapat dikatakan bahwa kegiatan pembelajaran matematika dengan menggunakan model pembelajaran Discovery Learning berbantuan alat peraga dadu mengalami peningkatan dan hasilnya maksimal. 
Hal ini dapat dilihat dari presentase di setiap indikator pemahaman konsep matematika peserta didik. Kegiatan pembelajaran matematika pada siklus II ini peserta didik sudah tidak ramai dan sudah dapat menempatkan posisinya ketika disuruh untuk berkelompok, peserta didik sudah dapat melaksanakan kegiatan pembelajaran dengan baik sesuai lembar kerja yang telah diberikan guru matematika. Banyak peserta didik yang sudah aktif dalam kelompoknya masing-masing untuk menyelesaikan permasalahan yang peneliti berikan selama proses pembelajaran berlangsung. Peserta didik sudah tidak mengalami kebingungan dalam menyelesaikan masalah yang diberikan oleh guru matematika sehingga peserta didik lebih tenang selama proses pembelajaran berlangsung.

Pada siklus II pertemuan kedua, peserta didik sudah dapat mengerjakan soal matematika tanpa menyontek teman lain. Penelti sudah bertindak tegas kepada peserta didik yang apabila mencontek akan diberikan hukuman, sehingga selama tes pemahaman konsep matematika dilaksanakan keadaan kelas sudah mulai tenang dan dapat terkondisikan dengan baik. Model pembelajaran Discovery Learning berbantuan alat peraga dadu sangatlah cocok untuk digunakan dalam pembelajaran matematika khususnya pada materi peluang kejadian majemuk pada peserta didik kelas XII MIPA 5 SMAN 1 Ampek Angkek, Kabupaten Agam, Sumatera Barat. Data yang diproleh dalam penelitian tentang pemahaman konsep matematika peserta didik kelas XII MIPA 5 SMAN 1 Ampek Angkek, Kabupaten Agam, Sumatera Barat mulai siklus I dan siklus II disajikan dalam tabel 1

Tabel 1. Persentase Peningkatan Pemahaman Perserta Didik Tentang Konsep Peluang kejadian majemuk Kejadian Majemuk Siklus I dan Siklus II

\begin{tabular}{|c|c|c|c|}
\hline \multirow{2}{*}{$\begin{array}{c}\text { No. } \\
\text { a. }\end{array}$} & Indikator Pemahaman Konsep & \multicolumn{2}{|c|}{ Tindakan } \\
\hline & Menyatakan ulang sebuah konsep & Siklus I & Siklus II \\
\hline b. & Mengklasifikasi objek menurut sifat-sifat & $70,21 \%$ & $81,20 \%$ \\
\hline c. & $\begin{array}{l}\text { Memberikan contoh konsep peluang } \\
\text { kejadian majemuk }\end{array}$ & $70,47 \%$ & $80,30 \%$ \\
\hline d. & $\begin{array}{l}\text { Menyajikan konsep peluang kejadian } \\
\text { majemuk }\end{array}$ & $69,81 \%$ & $80,21 \%$ \\
\hline e. & $\begin{array}{l}\text { Mengembangkan syarat perlu/syarat cukup konsep } \\
\text { peluang kejadian majemuk }\end{array}$ & $71,26 \%$ & $81,25 \%$ \\
\hline f. & $\begin{array}{l}\text { Menggunakan dan memanfaatkan prosedure } \\
\text { peluang kejadian majemuk }\end{array}$ & $72,13 \%$ & $82,40 \%$ \\
\hline g. & $\begin{array}{l}\text { Mengaplikasikan konsep peluang kejadian majemuk } \\
\text { dalam pemecahan masalah }\end{array}$ & $69,98 \%$ & $80,18 \%$ \\
\hline
\end{tabular}

Dalam pembahasan tentang peningkatan pemahaman konsep peluang melalui model pembelajaran Discovery Learning berbantuan alat peraga dadu selaras dengan penelitian [8] yang membahas tentang penggunaan alat peraga dadu dapat meningkatkan pemahaman konsep sehingga dapat meningkatkan hasil belajar peserta didik. Faktor yang mendukung adanya peningkatan pemahaman konsep yaitu ketertarikan peserta didik terhadap penggunaan alat peraga yang membuat peserta didik bersemangat selama pembelajaran berlangsung sehingga pebelajaran yang disampaikan oleh guru dapat diterima peserta didik serta penggunaan alat peraga yang sesuai dengan model pembelajaran yang dipakai sehingga akan berpengaruh terhadap tingkat pemahaman konsep peserta didik. Penelitian [9] dan [10] ini juga 
sependapat dengan [11] tentang pengaruh permainan terhadap kemampuan berhitung penjumlahan peserta didik dengan tujuan untuk menerapkan sebuah permainan yang dapat mengatasi permasalahan berhitung penjumlahan pada peserta didik. Penggunaan permainan yang diterapkan sebagai alat peraga dapat meningkatkan pemahaman konsep peserta didik. Penelitian ini juga sependapat dengan hasil penelitian [12] tentang keberhasilan peserta didik dalam belajar dapat dilihat dari pemahaman konsep peserta didik dan strategis matematis. Pemahaman konsep peserta didik dan strategis matematis akan berpengaruh terhadap nilai peserta didik serta dapat sebagai tolat ukur keberhasilan guru dalam pembelajarannya.

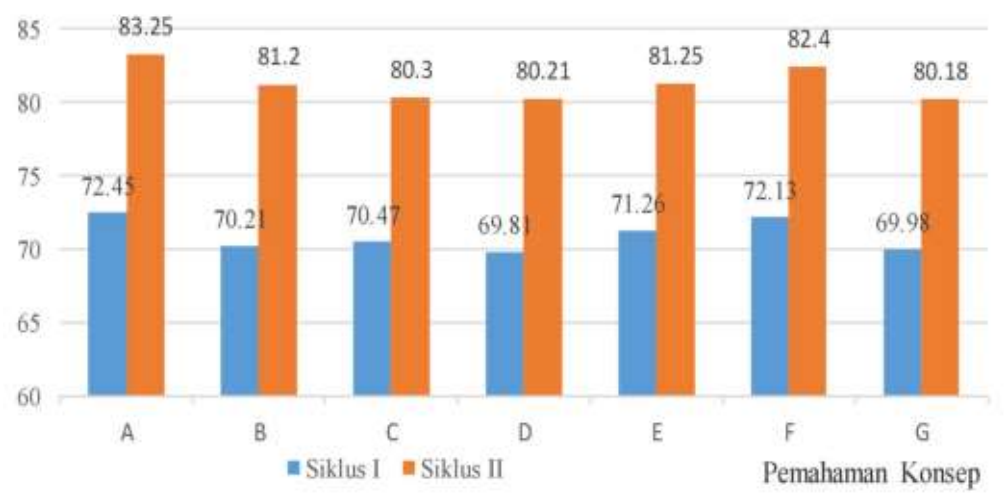

Keterangan Grafik:

A. Menyatakan ulang sebuah konsep

Mengklasifikasi objek menurut sifat-sifat

Memberikan contoh konsep peluang kejadian majemuk

Menyajikan konsep peluang kejadian majemuk

Mengembangkan syarat perlu/syarat cukup konsep peluang kejadian majemuk

Menggunakan dan memanfaatkan prosedure peluang kejadian majemuk

Mengaplikasikan konsep peluang kejadian majemuk dalam pemecahan masalah

Gambar 1. Persentase Peningkatan Pemahaman Peserta Didik Tentang Konsep Peluang kejadian majemuk Kejadian Majemuk Siklus I dan Siklus II

Penggunaan alat peraga yang dipakai haruslah selaras dengan penggunaan model pembelajaran yang diterapkan sehingga materi yang diajarkan dapat dipahami oleh peserta didik dan dapat meningkatkan pemahaman konsep peserta didik. Penggunaan model pembelajaran Discovery Learning sangatlah cocok untuk dipadukan dengan penggunaan alat peraga dadu. Model pembalajaran Discovery Learning merupakan model pembelajaran yang berpusat pada peserta didik dimana model pembelajaran ini bersifat penemuan yang artinya peserta didik akan dituntut untuk menyelesaikan permasalahan yang diberikan oleh guru sehingga peserta didik dapat menemukan rumus atau materi yang diajarkan. Penelitian ini sependapat dengan hasil penelitian [13] menyimpulkan bahwa penerapan penggunaan model pembelajaran Discovery Learning dapat meningkatkan pemahaman konsep peserta didik serta dapat meningkatkan kemampuan guru dalam menerangkan materi sehingga hasil belajar peserta didik dapat optimal. Penggunaan model pembelajaran Discovery Learning ini dapat membuat peserta didik lebih aktif selama proses pembelajaran berlangsung.

Selain itu penelitian ini sependapat dengan hasil penelitian [14] menyimpulkan bahwa penggunaan model pembelajaran Discovery Learning dapat 
meningkatkan pemahaman konsep peserta didik serta dapat meningkatkan hasil belajar peserta didik. Keberhasilan peserta didik dan keberhasilan guru dalam mengajar dapat dilihat dari hasil belajar peserta didik dimana hasil belajar peserta didik pastinya didapatkan dari suatu pemahaman konsep pembelajaran tertentu. Penelitian ini juga sependapat dengan [15] mengemukakan bahwa penggunaan model pemebelajaran Discovery Learning lebih baik dari pada penggunaan model pembelajaran konvensional dimana dengan penggunaan model pembelajaran Discovery Learning ini peserta didik lebih aktif dan berfikir kritis. Penelitian [16] ini juga sependapat dengan [17] menyimpulkan bahwa nilai rata-rata hasil belajar tematik peserta didik dengan model pembelajaran Discovery Learning lebih tinggi dari pada nilai rata-rata hasil belajar tematik peserta didik dengan model pembelajaran konvensional. Penggunaan model pembelajaran konvensional ini membuat peserta didik merasa bosan dan peserta didik kurang aktif selama pembelajaran berlangsung.

Penelitian ini [18] sependapat dengan teori Bruner (1996) yang juga dikenal dengan nama belajar penemuan (Discovery Learning). Teori Bruner menganggap bahwa belajar dengan model pembelajaran Discovery Learning akan membuat peserta didik lebih aktif dan membuat peserta didik akan lebih faham terhadap konsep yang dipelajari. Peranan guru dalam penggunaan model pembelajaran ini tidak terpusat dan guru hanya sebagai pembimbing atau fasilitator menyadari bahwa model pembelajaran Discovery Learning ini akan memerlukan waktu yang lama, menurut [19] penggunaan modelpembelajaran Discovery Learning ini hanya diterapkan sampai batas-batas tertentu yaitu dengan mengarahkannya hanya pada materi-materi tertentu.

\section{SIMPULAN DAN SARAN}

Penelitian ini merupakan penelitian tindakan kelas yang dilakukan dengan dua siklus dengan masing-masing setiap siklus dilakukan dua kali pertemuan yaitu pertemuan pertama untuk menerapkan model pebelajaran Discovery Learning berbantuan alat peraga dadu dan pertemuan kedua untuk tes pemahaman konsep. Berdasarkan penelitian yang telah dilakukan tentang peningkatan pemahaman konsep peluang pada materi peluang kejadian majemuk melalui model pembelajaran Discovery Learning berbantuan alat peraga dadu pada peserta didik kelas XII MIPA 5 SMAN 1 Ampek Angkek, Kabupaten Agam, Sumatera Barat, kejadian majemuk terdapat peningkatan pemahaman konsep peluang peserta didik dari sebelumnya, dapat dilihat pada hasil tes pemahaman konsep matematika peserta didik. dari siklus I sampai siklus II.

Rata-rata persentase peningkatan pemahaman konsep siklus I dan siklus II terhadap tindakan dari setiap indikator tes pemahaman konsep materi peluang kejadian majemuk berbantuan alat peraga dadu antara lain: 1) menyatakan ulang sebuah konsep dari 72,45\% menjadi 83,25\%, 2) mengklasifikasi objek menurut sifat-sifat dari 70,54\% menjadi $81,20 \%$, 3) memberikan contoh konsep peluang kejadian majemuk dari $70,47 \%$ menjadi $80.30 \%$, 4) menyajikan konsep peluang kejadian majemuk dari $69,81 \%$ menjadi $80,21 \%$, 5) mengembangkan syarat perlu/syarat cukup konsep peluang kejadian majemuk dari $71,26 \%$ 
menjadi $81,26 \%, 6)$ menggunakan dan memanfaatkan prosedure peluang kejadian majemuk dari 72,13\% menjadi 82,40\%, dan 7) mengaplikasikan konsep peluang kejadian majemuk dalam pemecahan masalah dari 69,98\% menjadi 80.18\%.

\section{REFERENSI}

[1] Cholik, M \& Sugijono .( 2007). Matematika 3A Untuk SMP Kelas IX Semester 1. Jakarta : PT. Gelora Aksara Pratama.

[2] Hasugian, Haloman.(2013). Meningkatkan Hasil Belajar Siswa Dalam Pembelajaran Matematika Dengan Metode Discovery Learning Pada Siswa Kelas VI Sekolah Dasar Negeri 02 Sejaruk Param.

[3] Ibrahim, Suparni. (2009). Strategi Pembelajaran Matematika . Teras : sukses offset.

[4] Istiana, G. A., Catur, A. N., \& Sukardjo, J.S.(2015). Penerapan Model Pembelajaran Discovery Learning Untuk Meningkatkan Aktivitas Prestasi Belajar Pokok Bahasan Larutan Penyangga Pada Siswa Kelas XI IPA. Jurnal Pendidikan Kimia (JPK), Vol. 4 No.2.

[5] Kristin, Firosalia.(2016). Analisis Model Pembelajran Discovery Learning Dalam Meningkatkan Hasil Belajar Siswa SD. Jurnal Pendidikan Dasar PerKhasa, Volume 2,Nomer 1.Diakses pada 28 oktober 2017

[6] Lestari, K. E \& Yudhanegara, M. R.(2015). Penelitian Penelitian Matematika. Karawang: PT Refika Aditama.

[7] Mangunsuwito.(2013). KAMUS SAKU BAHASA INDONESIA. Jakarta : Widyatamma Pressindo.

[8] Martini. (2011). Pembelajaran Standar Proses Berkarakter. Jakarta : Pranada Media Grup.

[9] Mulyatiningsih, Dra. E.(2011). Metode Penelitian Terapan Bidang Pendidikan. Yogyakarta: ALVABETA CV.

[10]Muslich, Mansur.(2009). Melaksanakan PTK Itu Mudah. Jakarta : PT Bumi Aksara.

[11]Ngatiman .(2011). Meningkatkan Hasil Belajar Matematika siswa Menggunakan Alat Peraga Asli Pada Siswa Kelas IV SDN 1 Tambahrejo.

[12] Nurfarikhin, Fuad. ( 2010 ). Hubungan Kemampuan Pemahaman Konsep Dan Kemampuan Penalaran Dengan Kemampuan Pemecahan Masalah Pada Materi Bangun Ruang Sisi Lengkung Peserta Didik Kelas IX MTs NU 24 Darul Ulum Kulon Patebon Kendal . Skripsi . Fakultas Tarbiyah Institut Agama Islam Negri Walisongo Semarang

[13] Nursupianah, Indah \& Ani, Aan.(2010). Pengaruh Penggunaan Alat Peraga Lingkaran Terhadap Hasil Belajar Siswa Kelas VIII Pada Pembelajaran Keliling Dan Luas Lingkaran. Jurnal Edukasi Matematika, Volume. 2 No 1

[14] Rismayani, Niluh.(2013). Penerapan Model Pembelajaran Discovery ～Learning Untuk Meningkatkan Hasil Belajar Pkn Siswa.

[15]Sanjaya, Wina.(2009). Penelitian Tindakan Kelas. Jakarta : Kencana Pranada Media Group.

[16] Sobel, Max \& Evan. (2003). Mengajar Matematika . jakarta : PT. Gelora Aksara Pratama. 
[17] Subadi .(2013). Meningkatkan Hasil Belajar Siswa Dengan Menggunakan Alat Peraga Melalui Model Pembelajaran Cooperatif Learning Metode Stad Pada Materi Pokok Bangun Datar Ruang Sisi Lengkung. Jurnal Volume. 01 Nomer. 01. Diakses pada 10 Oktober 2017

[18]Supardi . ( 2015) . Penilaian Autentik Pembelajaran Afektif, Kognitif Dan Psikomotosik ( Konsep dan Aplikasi). Jakarta : Pt Raja Grafindo Persada.

[19]Suwardi ., Firmiani, M. E ., dan Rohayati.(2014). Pengaruh Penggunaan Alat Peraga Terhadap Hasil Pembelajaran Matematika Pada Anak Usia Dini. Jurnal Al-Azhar Indonesia Seri Humaniora, Vol. 2 no. 4. 